\title{
FORMATION OF A CORROSION-RESISTANT ALUMINA COATING ON A 6061 ALUMINUM ALLOY USING A COMBINATION OF MICRO-ARC OXIDATION AND SEALING TREATMENTS
}

\author{
TVORBA KOROZIJSKO OBSTOJNE $\mathrm{Al}_{2} \mathrm{O}_{3}$ PREVLEKE NA ZLITINI \\ ALUMINIJA 6061 S KOMBINACIJO OKSIDACIJE V \\ MIKROOBLOKU IN POSTOPKA TESNJENJA
}

\author{
Ahmet Hilmi Paksoy, Faiz Muhaffel, Merve Koca, Ozge Gokce, \\ Sanaz Mohammadzadeh, Huseyin Cimenoglu \\ Istanbul Technical University, Department of Metallurgical and Materials Engineering, 34469 Istanbul, Turkey \\ cimenogluh@itu.edu.tr
}

Prejem rokopisa - received: 2015-09-24; sprejem za objavo - accepted for publication: 2015-12-24

doi:10.17222/mit.2015.302

\begin{abstract}
Micro-arc oxidation (MAO) is an attractive process for the fabrication of protective coatings on aluminum alloys used in many industrial applications, such as automotive, structural and aerospace. However, improvements in the corrosion resistance of aluminum alloys upon covering their surfaces with MAO coating may not be sufficient for extending the service life of the components utilized in harsh environments. In the present study, the MAO coating formed on a 6061 aluminum alloy was sealed using a stearic acid treatment. In the scope of the present study, the surface and cross-sectional microstructures and the phases of the MAO coatings were analyzed using scanning electron microscopy (SEM) and X-ray diffraction (XRD) techniques, respectively. The wettability and surface roughness of the samples were measured by goniometer and profilometer, respectively. The corrosion resistance was assessed by long-term immersion in $3.5 \%$ of mass fractions $\mathrm{NaCl}$ solution. Finally, it is concluded that sealing of the MAO coating by stearic acid treatment significantly improved the corrosion resistance of the 6061 quality aluminum alloy as compared to the untreated state and the unsealed MAO state.

Keywords: aluminum alloy, micro-arc oxidation, ceramic coating, sealing, corrosion.
\end{abstract}

\begin{abstract}
Oksidacija v mikroobloku (MAO) je zanimiv postopek za izdelavo zaščitnih nanosov na aluminijevih zlitinah, ki se jih uporablja v številnih industrijah, kot je avtomobilska, gradbeništvo in letalstvo. Vendar pa izboljšanje korozijske odpornosti aluminijevih zlitin po prekritju z MAO nanosom ni dovolj veliko za podaljšanje zdržljivosti komponent, ki se jih uporablja v kislih okoljih. V študiji je bila plast MAO, ki je nastala na zlitini aluminija 6061, zatesnjena z obdelavo s stearinsko kislino. V okviru te študije, so bile analizirane površine in mikrostrukture preseka in faze v MAO nanosu, s pomočjo elektronske vrstične mikroskopije (SEM) in $\mathrm{z}$ rentgensko difrakcijo (XRD). Omočljivost in hrapavost površine vzorcev sta bili izmerjeni $\mathrm{z}$ goniometrom in $\mathrm{s}$ profilometrom. Korozijska odpornost je bila določena z dolgotrajnim namakanjem v 3,5 \% raztopini NaCl. Ugotovljeno je bilo, da tesnjenje MAO nanosa $\mathrm{z}$ obdelavo $\mathrm{v}$ stearinski kislini, močno izboljša korozijsko odpornost aluminijeve zlitine $6061 \mathrm{v}$ primerjavi z neobdelanim stanjem ali z nezatesnjenim MAO.

Ključne besede: aluminijeva zlitina, oksidacija v mikroobloku, keramičen nanos, tesnjenje, korozija
\end{abstract}

\section{INTRODUCTION}

Aluminum alloys are the most commonly used weight-saving materials and preferred especially in the automotive, aerospace, military, marine and rail industries owing to their excellent mechanical properties, such as a high strength/weight ratio, resilience under static and dynamic loading, and good formability. ${ }^{1,2}$ Aluminum alloys are known for their good corrosion resistance due to the natural oxide film on their surface, consisting of oxyhydroxides $(\alpha-\mathrm{AlOOH}, \quad$ diaspore; $\gamma-\mathrm{AlOOH}$, boehmite or pseudo-boehmite) or aluminum hydroxides $\left(\mathrm{Al}(\mathrm{OH})_{3}\right.$, gibbsite bayerite) with a thickness of $4-10$ $\mathrm{nm}$. The oxide film is formed at any temperature when the aluminum alloy contacts with air or an oxidizing medium. ${ }^{3-5}$ However, this natural oxide layer is not sufficiently protective against chloride-containing media.
The high solubility of the natural oxide film in the chloride ions containing media leads to severe corrosion after a relatively short service life. ${ }^{6}$ Chloride ions are greatly absorbed on the natural oxide film and cause deep ruptures into the surface. ${ }^{7}$ The generation of these ruptures and the dissolution of the oxide phases disrupt the film continuity and cause the propagation of corrosion. To overcome the corrosion-related problems, the interaction of the surface and corrosive environment must be disconnected. Therefore, the studies were concentrated on surface modification such as micro-arc oxidation (MAO), hard anodizing, physical vapor deposition (PVD), laser surface treatment, cold spraying (CS) and sol-gel..$^{8-11}$

MAO is a technique that can be used to fabricate ceramic coatings on the surface by the plasma-assisted electrochemical conversion of aluminum. The ceramic coating consists mainly of a multi-layer structure which 


\section{MATERIALI IN TEHNOLOGIJE/MATERIALS AND TECHNOLOGY (1967-2017) - 50 LET/50 YEARS}

\section{A. H. PAKSOY et al.: FORMATION OF A CORROSION-RESISTANT ALUMINA COATING ON A 6061 ALUMINUM ALLOY ...}

is comprised of a relatively dense polycrystalline layer of alpha-alumina $\left(\alpha-\mathrm{Al}_{2} \mathrm{O}_{3}\right)$ as the inner layer, and a more porous gamma-alumina $\left(\gamma-\mathrm{Al}_{2} \mathrm{O}_{3}\right)$ layer as the outer layer. In the scope of wear and corrosion resistance, alumina coatings exhibit better surface properties than an aluminum substrate. ${ }^{12}$ Although previous studies have shown that the MAO treatment remarkably enhances the corrosion resistance of the aluminum alloys, the corrosion protection of the coating may fail under highly concentrated corrosive media and/or longer periods of interaction between the corrosive media and the coating. Moreover, the MAO coatings have micro-pores on the surface and cracks due to the nature of the oxide-forming mechanism and the thermal stresses generated by rapid cooling. Unfortunately, corrosive media can move along the cavities of the alumina coating and reach the aluminum substrate, which causes the generation of corrosion under the coating. ${ }^{13-15}$

In this respect, a post-treatment is required to improve and extend the corrosion resistance of the MAO coating on an aluminum alloy. The sealing is a cost-effective and simple post-treatment that provides the closure of micro pores and micro cracks in order to hinder the migration of the corrosive media through the alumina coating. ${ }^{16-20}$

The present study is aimed at improving the corrosion resistance of MAO formed alumina coating by a simple sealing post-treatment. The sealing treatment was performed by immersion in a hot stearic-acid-containing solution. After the microstructural and compositional analyses, the influence of the sealing treatment on the wettability and corrosion resistance of the MAO coating was investigated.

\section{EXPERIMENTAL PART}

The samples were cut to a size of $15 \mathrm{~mm} \times 15 \mathrm{~mm}$ from 6061 aluminum alloy and ground by $\mathrm{SiC}$ abrasive papers up to \#2500. A 30-kW DC power supply with a stainless-steel container serving as the cathode was used in the MAO process. The samples treated in an electrolyte containing $20 \mathrm{~g} / \mathrm{L}$ sodium aluminate (VWR International LLC) and $3 \mathrm{~g} / \mathrm{L}$ potassium hydroxide (VWR International LLC) for $5 \mathrm{~min}$ with an applied voltage of $450 \mathrm{~V}$ in the positive half cycle and $60 \mathrm{~V}$ in the negative half cycle. The pulse frequency and duty cycle were 588 $\mathrm{Hz}$ and $60 \%$, respectively. During the process, the temperature of the electrolyte was below $30{ }^{\circ} \mathrm{C}$ using an external cooling system. After the MAO treatment, samples were washed with ethanol, distilled water and dried in air at room temperature. For the sealing treatment, the samples were immersed in an ethanol solution of $0.1 \mathrm{~mol} / \mathrm{L}$ stearic acid at $65{ }^{\circ} \mathrm{C}$ for $1 \mathrm{~h}$ and then dried at $60{ }^{\circ} \mathrm{C}$ for $2 \mathrm{~h}$. The untreated alloy, sealed alloy, MAO treated and sealed MAO treated samples will be coded as Al-6061, Al-6061+S, MAO, and MAO+S, respectively.

The surface morphology and cross-sectional microstructure of the MAO coating were examined with a scanning electron microscope (SEM, Hitachi TM-1000). The phase composition of the MAO coating was identified by an X-ray diffractometer (XRD, Bruker D8 Advanced) using $\mathrm{Cu}-K \alpha$ radiation $(\lambda=0.154 \mathrm{~nm})$ at $40 \mathrm{kV}$ and $30 \mathrm{~mA}$ with a scan range of $20-90^{\circ}$. Contact angle measurements were performed using a goniometer (KSV CAM 200). Distilled water was used for the test and the drop volume was $5 \mu \mathrm{L}$. Five measurements were performed for each sample at room temperature.

The samples were immersed in $3.5 \%$ of mass fractions of $\mathrm{NaCl}$ solution for $(2,4,6$ and 14) d to evaluate the corrosion-resistant performance of the samples. The samples were removed from the $3.5 \%$ of mass fractions of $\mathrm{NaCl}$ solution, cleaned in deionized water and subsequently in ethanol to remove the remaining $\mathrm{NaCl}$ residues and dried at ambient temperature. The samples were weighed using an electronic balance with an accuracy of $0.1 \mathrm{mg}$ before and after the corrosion tests. The corrosion products were investigated using an energy-dispersive spectrometer (EDS, Oxford Instruments) in a Hitachi TM-1000 SEM. The corroded surfaces were observed by macro photography.
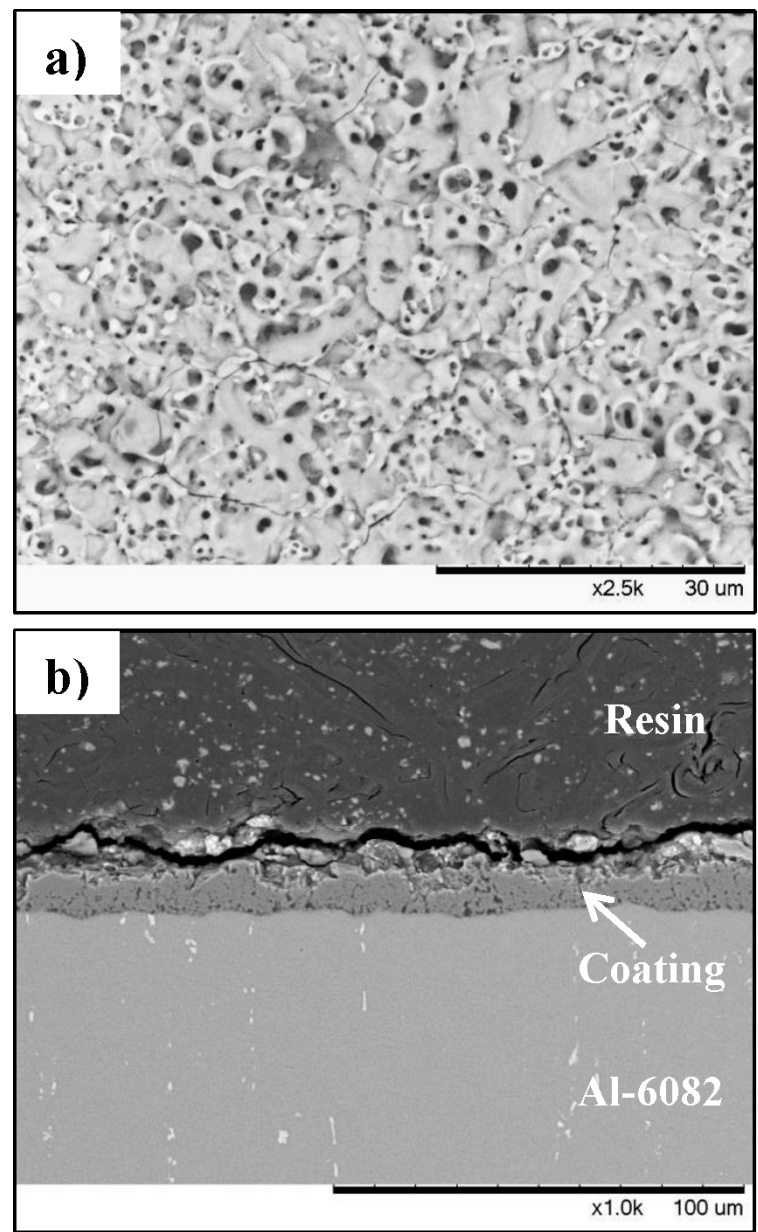

Figure 1: a) Surface and b) cross-sectional SEM images of the MAO sample

Slika 1: a) Površina in b) SEM-posnetek prečnega prereza vzorca $\mathrm{MAO}$ 
A. H. PAKSOY et al.: FORMATION OF A CORROSION-RESISTANT ALUMINA COATING ON A 6061 ALUMINUM ALLOY ...

\section{RESULTS AND DISCUSSION}

The surface and cross-section SEM micrograph of the MAO sample are shown in Figure 1. The coating showed the typical surface appearance of MAO process. The surface was covered with a coating containing spherical micro pores, micro cracks, crater-shaped structures as the result of the formation of discharge channels during the MAO process. Micro-cracking of the MAO coating is mainly associated with the thermal stress initiated during rapid solidification of the alumina melted in the discharge tunnel. ${ }^{21}$ The micro-pores were mainly ranged from about $1 \mu \mathrm{m}$ to $3 \mu \mathrm{m}$ in diameter. The thickness of the MAO coating was about $12 \mu \mathrm{m}$. Crosssection examinations revealed that the inner section of the MAO coating was denser than the outer section and showed a good bonding with the underlying substrate without any delamination and/or separation.

The XRD spectrum of the MAO-coated sample is presented in Figure 2. The MAO coating consisted of aluminum oxides in the form of $\alpha$-alumina $\left(\alpha-\mathrm{Al}_{2} \mathrm{O}_{3}\right)$ and $\gamma$-alumina $\left(\gamma-\mathrm{Al}_{2} \mathrm{O}_{3}\right)$. The aluminum peak appeared due to the penetration of $\mathrm{X}$-ray into the substrate. It is suggested that the outer sections of the MAO coating were primarily dominated by $\gamma-\mathrm{Al}_{2} \mathrm{O}_{3}$ owing to the higher cooling rate, while the inner section was mainly comprised of $\alpha-\mathrm{Al}_{2} \mathrm{O}_{3}$ as a result of more heat input gained during the MAO process. ${ }^{15,21}$

In Figure 3 contact angles measured on the as-received alloy (Al-6061), micro-arc oxidized alloy (MAO), sealed as-received alloy $(\mathrm{Al}-6061+\mathrm{S})$ and sealed MAO applied alloy (MAO+S) are presented. The as-received 6061 aluminum alloy and MAO samples exhibited low contact angles, as indicated by the high hydrophilicity and patelliform shape. The three times increase in the contact angle and the spherical shape of droplets showed that the stearic acid sealing treatment modified the surface to be more hydrophobic. Earlier studies have re-

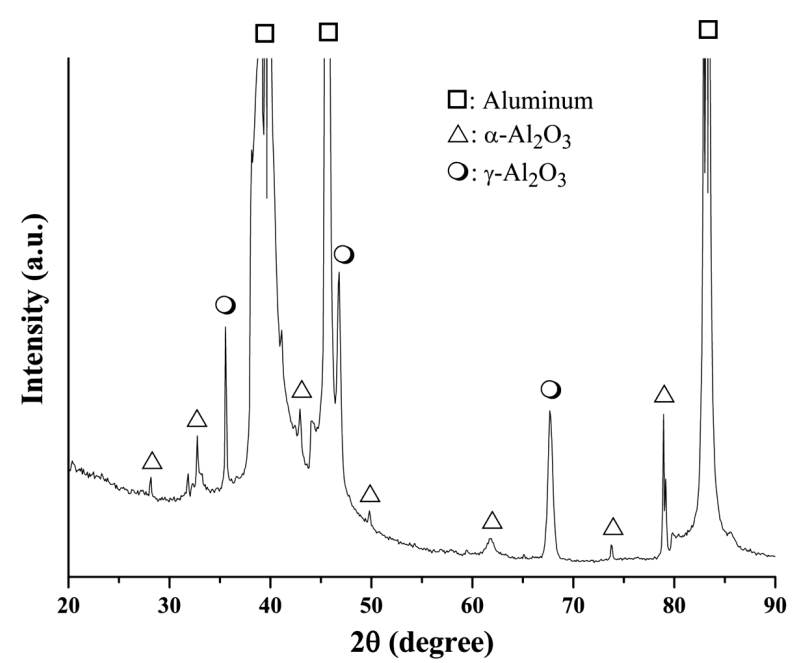

Figure 2: XRD spectrum of the MAO sample Slika 2: Rentgenogram vzorca MAO

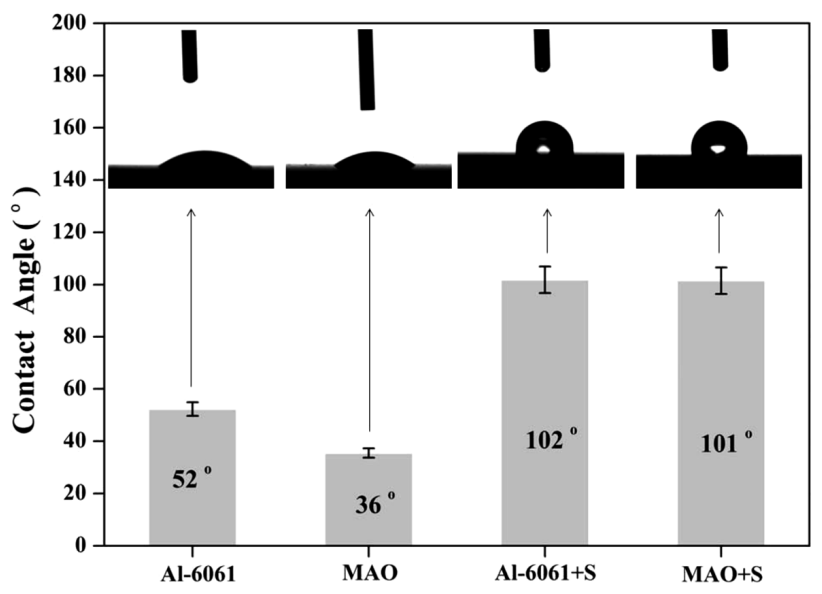

Figure 3: Contact-angle values of the samples and corresponding droplet images

Slika 3: Vrednosti kontaktnih kotov vzorcev in ustrezen posnetek kapljice

ported that hydrophobic surfaces provide relatively better corrosion protection in liquid media as compared to hydrophilic surfaces. ${ }^{22-24}$

The results of the corrosion tests are presented in Figure 4 as the weight gain of the samples with respect to the immersion time in $3.5 \%$ of mass fractions $\mathrm{NaCl}$ solution. As a general trend, the weight gain of the samples increased with an increasing duration time in the $3.5 \%$ of mass fractions of $\mathrm{NaCl}$ solution and the highest weight gain values were obtained from the samples coded as Al-6061 and Al-6061+S after the immersion time of $14 \mathrm{~d}$. In order to understand the reason for the weight gain, the Al-6061 sample immersed in the 3.5\% of mass fractions of $\mathrm{NaCl}$ solution was subjected to SEM examinations. As can be seen in Figure 5, the surroundings of the pits were enriched by chloride species, as reported previously. ${ }^{5}$

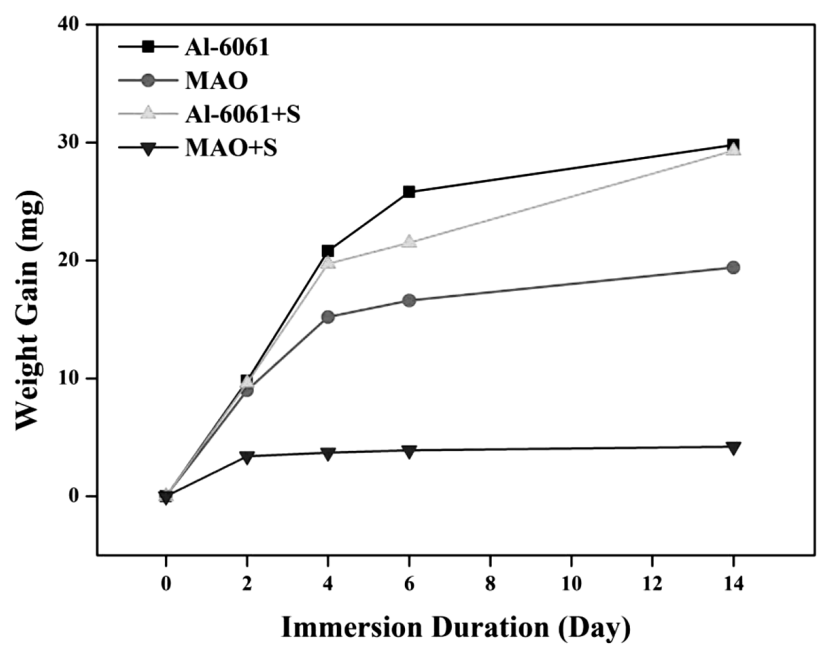

Figure 4: Corrosion weight gain - immersion duration plot of the samples

Slika 4: Pridobivanje teže zaradi korozije v odvisnosti od trajanja namakanja vzorcev 


\section{MATERIALI IN TEHNOLOGIJE/MATERIALS AND TECHNOLOGY (1967-2017) - 50 LET/50 YEARS}

A. H. PAKSOY et al.: FORMATION OF A CORROSION-RESISTANT ALUMINA COATING ON A 6061 ALUMINUM ALLOY ...

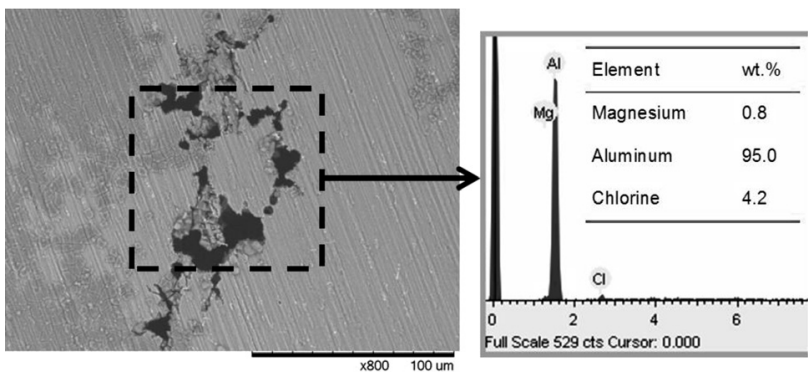

Figure 5: SEM micrograph and corresponding EDS analysis of Al-6061 sample after immersion in $3.5 \%$ of mass fractions of $\mathrm{NaCl}$ solution for 14 days

Slika 5: SEM posnetek in ustrezna EDS analiza vzorca Al-6061 po namakanju $14 \mathrm{dni}$ v raztopini $3,5 \% \mathrm{NaCl}$

As the results of following reactions listed below, various pitting corrosion products such as complex aluminum chloride $\left(\mathrm{AlCl}_{4}^{-}\right)$, aluminum hydroxide $\left(\mathrm{Al}(\mathrm{OH})_{3}\right)$ developed on the surface.

$$
\begin{gathered}
\mathrm{Al} \rightarrow \mathrm{Al}^{+3}+3 \mathrm{e}^{-} \\
\mathrm{Cl} \rightarrow \mathrm{Cl}^{-}+\mathrm{e}^{-} \\
\mathrm{Al}+4 \mathrm{Cl}^{-} \rightarrow \mathrm{AlCl}_{4}^{-} \\
\mathrm{Al}^{+3}+3 \mathrm{H}_{2} \mathrm{O} \rightarrow \mathrm{Al}(\mathrm{OH})_{3}+3 \mathrm{H}^{+}
\end{gathered}
$$

Among the examined samples, lowest weight gain was measured for the $\mathrm{MAO}$ and $\mathrm{MAO}+\mathrm{S}$ samples, indi- cating the good corrosion-protection characteristics of MAO coatings. The sealing treatment enormously enhanced the corrosion resistance of the MAO coating so that the weight gain of the $\mathrm{MAO}+\mathrm{S}$ sample was about five times lower than the MAO sample.

Macro images of the samples after immersion in $3.5 \%$ of mass fractions of $\mathrm{NaCl}$ solution for different durations are depicted in Figure 6. Even after a short immersion duration in the corrosion media ( $2 \mathrm{~d})$, the surface of the as-received 6061 aluminum sample turned to a dark color and contained many deep and wide pits. In general, the surface appearance of the sealed sample $(\mathrm{Al}-6061+\mathrm{S})$ exhibited similar features to that of the prior state of the corrosion test. The prolonged duration of the immersion also led the progress of corrosion on the surface of Al-6061+S sample completely. Unlike the Al-6061 and Al-6061+S samples, there was no severe pitting or deterioration as the indications of corrosion progress on the surfaces of MAO and $\mathrm{MAO}+\mathrm{S}$ samples. Only a slight darkening and some small pits were observed on the surface of the MAO sample after 14 days of immersion in $3.5 \%$ of mass fractions of $\mathrm{NaCl}$ solution.

It is obvious that the corrosive media were restricted to penetrate into the vicinities of the MAO coating by utilizing a stearic-acid -sealing treatment. Although the present approach showed a promising solution for corro-

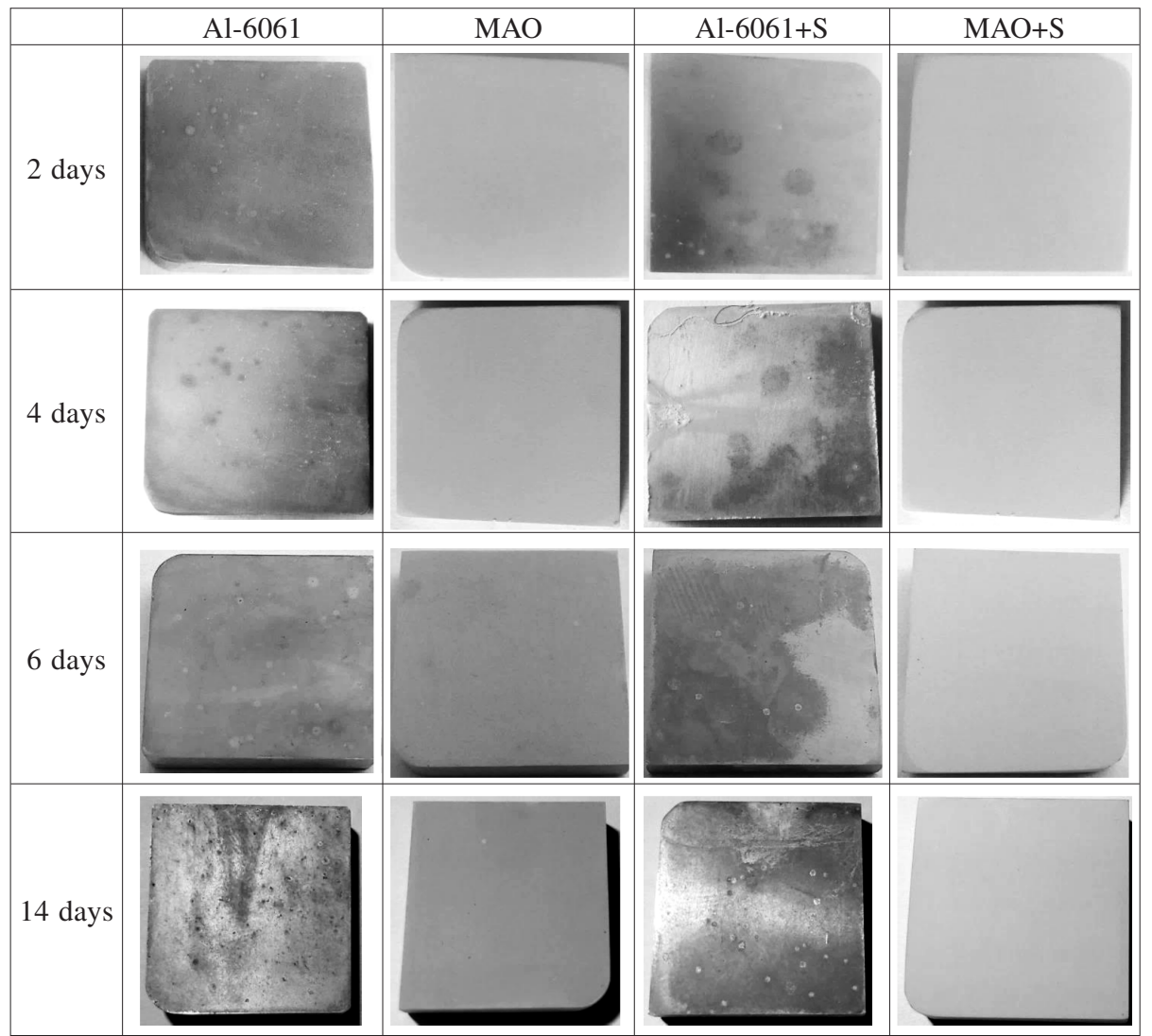

Figure 6: Macro images of the samples after immersion in $3.5 \%$ of mass fractions of $\mathrm{NaCl}$ solution for different immersion times Slika 6: Makroposnetek vzorca po različno dolgem namakanju v 3,5\% raztopini $\mathrm{NaCl}$ 


\section{MATERIALI IN TEHNOLOGIJE/MATERIALS AND TECHNOLOGY (1967-2017) - 50 LET/50 YEARS}

\section{A. H. PAKSOY et al.: FORMATION OF A CORROSION-RESISTANT ALUMINA COATING ON A 6061 ALUMINUM ALLOY ...}

sion protection of aluminum alloys, further studies are needed to be performed for understanding sealing mechanism and characterizing the modified MAO coating in more detailed.

\section{CONCLUSIONS}

The combination of MAO and sealing treatment with stearic acid was successfully applied to a 6061 aluminum alloy. The results demonstrated that when MAO or sealing treatments are separately applied the corrosion resistance of the examined aluminum alloy slightly improved. The sequential application of the MAO and the sealing treatment $(\mathrm{MAO}+\mathrm{S}$ sample) provided the best corrosion resistance for the longest period (14 d) of immersion in $3.5 \%$ of mass fractions of a $\mathrm{NaCl}$ solution.

\section{REFERENCES}

${ }^{1}$ A. Polat, M. Avsar, F. Ozturk, Effects of the artificial-aging temperature and time on the mechanical properties and springback behaviour of AA6061, Mater. Tehnol., 49 (2015), 487-493, doi:10.17222/ mit.2013.154

${ }^{2}$ W. S. Miller, L. Zhuang, J. Bottema, A. J. Wittebrood, P. De Smet, A. Haszler, A. Vieregge, Recent development in aluminium alloys for the automotive industry, Materials Science and Engineering A, 280 (2000), 37-49, doi:10.1016/S0921-5093(99)00653-X

${ }^{3}$ A. Raveh, Z. K. Tsameret, E. Grossman, Surface characterization of thin layers of aluminium oxide, Surface and Coatings Technology, 88 (1997), doi:103-111, 10.1016/S0257-8972(95)02757-2

${ }^{4}$ G. M. Scamans, N. Birbilis, R. G. Buchheit, Corrosion of Aluminum and its Alloys, Shreir's Corrosion, 2010, 1974-2010, doi:10.1016/ B978-044452787-5.00095-0

${ }^{5}$ C. Vargel, The Corrosion of Aluminium, 2004, doi:10.1016/B978008044495-6/50011-2

${ }^{6}$ A. Halap, M. Popovic, T. Radetic, V. Vascic, E. Romhanji, Influence of the thermo-mechanical treatment on the exfoliation and pitting corrosion of an AA5083-type alloy, Mater. Tehnol., 48 (2014), 479-483

${ }^{7}$ M. J. F. Gándara, Aluminium: The metal of choice, Mater. Tehnol., 47 (2013), 261-265

${ }^{8}$ Y. Bao, D. T. Gawne, J. Gao, T. Zhang, B. D. Cuenca, A. Alberdi, Thermal-spray deposition of enamel on aluminium alloys, Surface and Coatings Technology, 232 (2013), 150-158, doi:10.1016/ j.surfcoat.2013.04.065

${ }^{9}$ O. A. Gali, M. Shafiei, J. A. Hunter, A. R. Riahi, The tribological behavior of PVD coated work roll surfaces during rolling of aluminum, Surface and Coatings Technology, 260 (2014), 230-238, doi:10.1016/j.surfcoat.2014.06.071

${ }^{10}$ D. K. Merl, I. Milošev, P. Panjan, F. Zupanič, Morphology and corrosion properties PVD Cr-N coatings deposited on aluminium alloys, Mater. Tehnol., 45 (2011), 593-597

${ }^{11}$ J. Tian, Z. Luo, S. Qi, X. Sun, Structure and antiwear behavior of micro-arc oxidized coatings on aluminum alloy, Surface and Coatings Technology, 154 (2002), 1-7, doi:10.1016/S0257-8972(01) 01671-1
${ }^{12}$ H. Ding, Z. Dai, S. C. Skuiry, D. Hui, Corrosion wear behaviors of micro-arc oxidation coating of $\mathrm{Al} 2 \mathrm{O} 3$ on 2024Al in different aqueous environments at fretting contact, Tribology International, 43 (2010), 868-875, doi:10.1016/j.triboint.2009.12.022

${ }^{13}$ R. C. Barik, J. A. Wharton, R. J. K. Wood, K. R. Stokes, R. L. Jones, Corrosion, erosion and erosion-corrosion performance of plasma electrolytic oxidation (PEO) deposited A12O3 coatings, Surface and Coatings Technology, 199 (2005), 158-167, doi:10.1016/j.surfcoat. 2004.09.038

${ }^{14}$ L. Wen, Y. Wang, Y. Zhou, L. Guo, J. H. Ouyang, Microstructure and corrosion resistance of modified $2024 \mathrm{Al}$ alloy using surface mechanical attrition treatment combined with microarc oxidation process, Corrosion Science, 53 (2011), 473-480, doi:10.1016/j.corsci.2010. 09.061

${ }^{15}$ O. Tazegul, F. Muhaffel, O. Meydanoglu, M. Baydogan, E. S. Kayali, H. Cimenoglu, Wear and corrosion characteristics of novel alumina coatings produced by micro arc oxidation on AZ91D magnesium alloy, Surface and Coatings Technology, 258 (2014), 168-173, doi:10.1016/j.surfcoat.2014.09.035

${ }^{16}$ J. A. González, M. Morcillo, E. Escudero, V. López, E. Otero, Atmospheric corrosion of bare and anodized aluminium in a wide range of environmental conditions. Part I: Visual observations and gravimetric results', Surface and Coatings Technology, 153 (2002), 225-234, doi:10.1016/S0257-8972(01)01680-2

${ }^{17} \mathrm{X}$. Yu, C. Cao, Electrochemical study of the corrosion behavior of Ce sealing of anodized 2024 aluminum alloy, Thin Solid Films, 423 (2003), 252-256, doi:10.1016/S0040-6090(02)01038-6

${ }^{18}$ J. J. Suay, E. Giménez, T. Rodríguez, K. Habbib, J. J. Saura, Characterization of anodized and sealed aluminium by EIS, Corrosion Science, 45 (2003), 611-624, doi:10.1016/S0010-938X(02)00137-3

${ }^{19}$ M. A. Chen, S. Y. Liu, J. M. Li, N. Cheng, X. M. Zhang, Improvement to corrosion resistance of MAO coated 2519 aluminum alloy by formation of polypropylene film on its surface, Surface and Coatings Technology, 232 (2013), 674-679, doi:10.1016/j.surfcoat.2013.06. 073

${ }^{20}$ X. Cui, X. Lin, C. Liu, R. Yang, X. Zheng, and M. Gong, Fabrication and corrosion resistance of a hydrophobic micro-arc oxidation coating on AZ31 Mg alloy, Corrosion Science, 90 (2015), 402-412, doi:10.1016/j.corsci.2014.10.041

${ }^{21}$ T. Wei, F. Yan, J. Tian, Characterization and wear- and corrosionresistance of microarc oxidation ceramic coatings on aluminum alloy, Journal of Alloys and Compounds, 389 (2005), 169-176, doi:10.1016/j.jallcom.2004.05.084

${ }^{22}$ V. Bertola, M. Wang, Dynamic contact angle of dilute polymer solution drops impacting on a hydrophobic surface, Colloids and Surfaces A, 481 (2015), 600-608, doi:10.1016/j.colsurfa.2015. 05.052

${ }^{23}$ P. Wang, D. Zhang, R. Qiu, Y. Wan, J. Wu, Green approach to fabrication of a super-hydrophobic film on copper and the consequent corrosion resistance, Corrosion Science, 80 (2014), 366-373, doi:10.1016/j.corsci.2013.11.055

${ }^{24}$ Z. Wang, Q. Li, Z. She, F. Chen, L. Li, X. Zhang, P. Zhang, Facile and fast fabrication of superhydrophobic surface on magnesium alloy, Applied Surface Science, 271 (2013), 182-192, doi:10.1016/ j.apsusc. 2013.01 .158 